\title{
ANALISIS KADAR GLUKOSA PADA BIOMASSA BONGGOL PISANG MELALUI PAPARAN RADIASI MATAHARI, GELOMBANG MIKRO, DAN HIDROLISIS
}

\author{
ASAM
}

Oleh:

\author{
Qismatul Barokah ${ }^{1}$ dan Ahmad Abtokhi ${ }^{2}$
}

\begin{abstract}
ABSTRAK: Penelitian ini bertujuan untuk mengetahui pengaruh penambahan air dan perubahan kadar glukosa pada biomassa bonggol pisang melalui paparan radiasi matahari, gelombang mikro, dan hidrolisis asam. Metode penelitian dilakukan dengan cara mengeringkan bonggol pisang jenis pisang kepok selama 5 hari, kemudian dihomogenkan dengan proses penghalusan, setelah itu dilakukan tiga metode penghidrolisisan pati menjadi glukosa melalui paparan radiasi matahari, paparan gelombang mikro, dan hidrolisis asam. Pada setiap perlakuan pemaparan, sampel divariasi menjadi tiga yaitu kering, penambahan air $10 \mathrm{ml}$, dan penambahan air $20 \mathrm{ml}$, masing-masing perlakuan dilakukan pengulangan sebanyak 3 (tiga) kali. Kadar glukosa dianalisis dengan metode Nelson-Somogyi dan hasilnya dianalisis menggunakan perbandingan grafik.

Berdasarkan hasil penelitian, menunjukkan adanya pengaruh penambahan air dan metode yang digunakan terhadap kadar glukosa. Hasil analisis UV-Vis melalui analisis perbandingan grafik menunjukkan bahwa terdapat peningkatan kadar glukosa yang signifikan terutama ketika sampel dipapar menggunakan gelombang mikro serta dengan penambahan air $20 \mathrm{ml}$ yang menghasilkan kadar glukosa sebesar $30.89 \%$.
\end{abstract}

Kata Kunci: Kadar Glukosa, Bonggol Pisang, Gelombang Mikro, Radiasi Matahari, Hidrolisis Asam

\section{PENDAHULUAN}

Salah satu permasalahan serius yang dihadapi oleh banyak negara saat ini adalah jumlah bahan bakar fosil yang sangat terbatas sementara kebutuhan terus meningkat. Di lain pihak pemanasan global yang diakibatkan oleh pemakaian bahan bakar fosil semakin terasa. Kedua hal ini mendorong dikembangkannya bahan bakar alternatif yang bersifat terbarukan dan konservasi energi. Salah satu bentuk dari energi terbarukan adalah energi biomassa. Energi biomassa berasal dari bahan organik dan sangat beragam jenisnya. Sumber energi biomassa dapat berasal dari tanaman perkebunan atau pertanian, hutan, atau bahkan limbah, baik limbah domestik maupun limbah pertanian. Biomassa merupakan bentuk sumber energi yang menarik untuk dikembangkan karena kelimpahannya di muka bumi dan sifatnya yang dapat diperbarui. Biomassa dapat digunakan untuk sumber energi langsung maupun dikonversi menjadi bahan bakar. Penggunaan biomassa sebagai sumber energi ini tidak akan menyebabkan terjadinya penumpukan gas $\mathrm{CO}_{2}$ karena gas $\mathrm{CO}_{2}$ yang

\footnotetext{
${ }^{1}$ Mahasiswa Jurusan Fisika Fakultas Sains dan Teknologi UIN Maliki Malang

${ }^{2}$ Staf pengajar pada Jurusan Fisika Fakultas Sains dan Teknologi UIN Maliki Malang
} 
dihasilkan oleh reaksi pembakaran dipakai untuk pembentukan biomassa itu sendiri. Teknologi pemanfaatan energi biomassa yang telah dikembangkan terdiri dari pembakaran langsung dan konversi biomassa menjadi bahan bakar. Hasil konversi biomassa ini dapat berupa biogas, bioetanol, biodiesel, arang dan sebagainya. Bioetanol dan biodiesel dalam jangka panjang diharapkan dapat digunakan sebagai pengganti bahan bakar minyak. Etanol yang diproduksi dari biomassa pada saat ini adalah bahan bakar hayati (biofuel) yang banyak digunakan dengan mencampurkannya dengan bensin. Beberapa tahun belakangan ini, telah dilakukan pengembangan bahan bakar berbasis nabati yang dapat mengurangi pencemaran lingkungan, sehingga lebih ramah lingkungan.

Produksi bioetanol dari tanaman yang menghasilkan pati atau karbohidrat dapat dilakukan melalui konversi karbohidrat menjadi gula (glukosa) dengan beberapa proses, antara lain kimia, fisika, serta menggunakan pemanasan biasa. Beberapa penelitian tentang hal ini antara lain, penelian tentang penggabungan perlakuan gelombang mikro dan hidrolisis enzim pada Bambu didapatkan bahwa pemaparan gelombang mikro dapat mengubah struktur lignoselulosa subtrat bambu, serta jumlah gula produksi yang terbentuk oleh substrat bambu akibat pemaparan gelombang mikro naik hingga 2,3\% dibanding yang tidak mendapatkan paparan gelombang mikro [1]. Pada penelitian yang dilakukan oleh Septi (2010) didapatkan adanya pengaruh yang signifikan akibat radiasi gelombang mikro pada proses pembuatan biodesel pada minyak ikan, dengan daya yang semakin tinggi mampu meningkatkan hasil konversi biodesel. Daya yang optimum adalah 800 watt pada perbandingan mol minyak ikan dengan metanol sebesar 1:18 [2]. Penelitian lain yang mengenai efek paparan gelombang mikro terhadap peningkatan kadar glukosa pada Jerami Padi didapatkan konsentrasi kadar glukosa 2081,25 mmol/L pada penggunaan daya 1120 watt [2].

Berdasarkan penjelasan di atas perlu dilakukan penelitian tentang Analisis Kadar Glukosa pada Biomassa Bonggol Pisang melalui Paparan Radiasi Matahari, Gelombang Mikro, dan Hidrolisis Asam. Pemilihan bonggol pisang sebagai bahan pembuatan bioetanol adalah karena potensi kandungan pati pada bonggol pisang yang besar dapat dimanfaatkan sebagai alternatif bahan bakar yaitu bioetanol [3]. Penelitian ini dilakukan dengan tujuan mengetahui pengaruh penambahan kadar air terhadap kadar glukosa pada biomassa bonggol pisang melalui paparan radiasi matahari, gelombang mikro, dan hidrolisis asam, dan mengetahui perubahan kadar glukosa pada biomassa bonggol pisang melalui paparan radiasi matahari, gelombang mikro, dan hidrolisis asam. 


\section{HASIL DAN PEMBAHASAN \\ DESKRIPSI HASIL PENELITIAN}

Data yang diperoleh dari pembacaan absorbansi larutan standar glukosa terlihat pada tabel 2, kemudian dari data tersebut, dapat dibuat grafik persamaan garis linier sehingga diperoleh persamaan matematis $\mathrm{y}=0.00553 \mathrm{x}+0.00545$, dimana y adalah nilai absorbansi dari glukosa pada panjang gelombang $540 \mathrm{~nm}$ dan $\mathrm{x}$ adalah konsentrasi glukosa. Dari persamaan tersebut, maka diperoleh perhitungan konsentrasi glukosa sampel pada beberapa konsentrasi subtrat dengan menggunakan data hasil pengamatan nilai absorbansi dari tiap sampel.

Tabel 1. Nilai Absorbansi Standar Glukosa

\begin{tabular}{|c|c|}
\hline Konsentrasi Glukosa (ppm) & Absorbansi \\
\hline 5 & 0.0339 \\
\hline 15 & 0.0936 \\
\hline 25 & 0.1473 \\
\hline 35 & 0.1975 \\
\hline 45 & 0.2516 \\
\hline
\end{tabular}

Ketika nilai konsentrasi sudah diperoleh dari perhitungan regresi, kemudian dihitung jumlah kadar glukosa dengan memasukkan konsentrasi kedalam rumus:

$$
\text { Kadar glukosa }(\%)=\frac{(\text { Glukosa pada kurva standar })}{\text { sampel yang dianalisis }} \times 100 \%
$$

\section{A. Paparan Radiasi Sinar Matahari}

Tabel 2. Data Hasil Pengukuran Absorbansi dan Perhitungan Kadar Glukosa pada Sampel Paparan Radiasi Sinar Matahari

\begin{tabular}{|c|c|c|c|}
\hline Sampel & Absorbansi & $\begin{array}{c}\text { Kadar Glukosa } \\
(\boldsymbol{\%})\end{array}$ & $\begin{array}{c}\text { Rata-rata Kadar } \\
\text { glukosa (\%) }\end{array}$ \\
\hline \multirow{3}{*}{ Kering } & 0.0938 & 15.98 & \multirow{2}{*}{16.16} \\
\cline { 2 - 3 } & 0.0949 & 16.18 & \multirow{2}{*}{16} \\
\cline { 2 - 3 } & 0.0957 & 16.32 & \multirow{2}{*}{16.73} \\
\hline \multirow{3}{*}{ Basah 10 ml } & 0.0978 & 16.70 & \multirow{2}{*}{} \\
\cline { 2 - 3 } & 0.0981 & 16.76 & \\
\cline { 2 - 3 } & 0.0979 & 16.72 & \multicolumn{2}{|c}{} \\
\hline & 0.1053 & 18.06 & \multicolumn{2}{|c}{} \\
\hline
\end{tabular}




\begin{tabular}{|l|l|l|l|}
\hline Basah $20 \mathrm{ml}$ & 0.1058 & 18.15 & \multirow{2}{*}{18.12} \\
\cline { 2 - 3 } & 0.1058 & 18.15 & \\
\hline
\end{tabular}

\section{B. Paparan Gelombang Mikro}

Tabel 3. Data Hasil Pengukuran Absorbansi dan Perhitungan Kadar Glukosa pada Sampel Paparan Gelombang Mikro

\begin{tabular}{|c|c|c|c|}
\hline Sampel & Absorbansi & $\begin{array}{c}\text { Kadar Glukosa } \\
\qquad(\%)\end{array}$ & $\begin{array}{c}\text { Rata-rata Kadar } \\
\text { Glukosa }(\%)\end{array}$ \\
\hline \multirow{3}{*}{ Kering } & 0.1622 & 28.35 & \multirow{3}{*}{28.57} \\
\hline & 0.1637 & 28.62 & \\
\hline & 0.1643 & 28.73 & \\
\hline \multirow{3}{*}{ Basah $10 \mathrm{ml}$} & 0.1729 & 30.28 & \multirow{3}{*}{30.51} \\
\hline & 0.1736 & 30.41 & \\
\hline & 0.1758 & 30.81 & \\
\hline \multirow{3}{*}{ Basah $20 \mathrm{ml}$} & 0.1742 & 30.51 & \multirow{3}{*}{30.69} \\
\hline & 0.1727 & 30.67 & \\
\hline & 0.1739 & 30.89 & \\
\hline
\end{tabular}

\section{Hidrolisis Asam}

Tabel 4. Data Hasil Pengukuran Absorbansi dan Perhitungan Kadar Glukosa Pada Sampel Hidrolisis Asam

\begin{tabular}{|c|c|c|c|}
\hline Sampel & Absorbansi & $\begin{array}{c}\text { Kadar Glukosa } \\
(\%)\end{array}$ & $\begin{array}{c}\text { Rata-rata Kadar } \\
\text { Glukosa }(\%)\end{array}$ \\
\hline \multirow{3}{*}{ Kering } & 0.1323 & 22.94 & \multirow{3}{*}{22.96} \\
\hline & 0.1324 & 22.96 & \\
\hline & 0.1326 & 22.99 & \\
\hline \multirow{3}{*}{ Basah $10 \mathrm{ml}$} & 0.1373 & 23.84 & \multirow{3}{*}{23.89} \\
\hline & 0.1376 & 23.9 & \\
\hline & 0.1378 & 23.93 & \\
\hline \multirow{3}{*}{ Basah 20} & 0.1434 & 24.95 & \multirow{3}{*}{25.09} \\
\hline & 0.1445 & 25.15 & \\
\hline & 0.1447 & 25.18 & \\
\hline
\end{tabular}




\section{Perbandingan Kadar glukosa}

Tabel. Data Hasil Perolehan Kadar Glukosa dari Masing-masing Metode yang Digunakan

\begin{tabular}{|c|c|c|c|c|c|}
\hline \multirow[t]{2}{*}{ Metode } & \multirow[t]{2}{*}{ Sampel } & \multicolumn{3}{|c|}{ Kadar Glukosa (\%) } & \multirow{2}{*}{$\begin{array}{c}\text { Rata-rata Kadar } \\
\text { Glukosa }(\%)\end{array}$} \\
\hline & & 1 & 2 & 3 & \\
\hline \multirow{3}{*}{$\begin{array}{c}\text { Paparan } \\
\text { Radiasi } \\
\text { Matahari }\end{array}$} & Kering & 15.98 & 16.18 & 16.32 & 16.16 \\
\hline & Basah $10 \mathrm{ml}$ & 16.7 & 16.76 & 16.72 & 16.73 \\
\hline & Basah $20 \mathrm{ml}$ & 18.06 & 18.15 & 18.15 & 18.12 \\
\hline \multirow{3}{*}{$\begin{array}{c}\text { Paparan } \\
\text { Gelombang } \\
\text { Mikro }\end{array}$} & Kering & 28.35 & 28.62 & 28.73 & 28.57 \\
\hline & Basah $10 \mathrm{ml}$ & 30.28 & 30.41 & 30.81 & 30.51 \\
\hline & Basah $20 \mathrm{ml}$ & 30.51 & 30.67 & 30.89 & 30.69 \\
\hline \multirow{3}{*}{$\begin{array}{l}\text { Hidrolisis } \\
\text { Asam }\end{array}$} & Kering & 22.94 & 22.96 & 22.99 & 22.96 \\
\hline & Basah $10 \mathrm{ml}$ & 23.84 & 23.9 & 23.93 & 23.89 \\
\hline & Basah $20 \mathrm{ml}$ & 24.95 & 25.15 & 25.18 & 25.09 \\
\hline
\end{tabular}

\section{Pembahasan}

\section{A. Paparan Radiasi Matahari}

Bonggol pisang yang dipapar radiasi matahari akan menyerap cahaya dan energi yang dibawa oleh matahari, hal ini karena radiasi matahari membawa gelombang elektromagnetik yang menyebabkan adanya perpindahan panas. Ketika sinar matahari mengenai sampel, maka sampel akan menyerap gelombang dan cahaya yang dipancarkan sehingga sampel akan mengalami pemanasan akibat ada gelombang di serap oleh air, yang pada akhirnya akan menyebabkan penguapan. Akibat penguapan air dari dalam sampel maka kadar pati yang terdapat dalam sampel meningkat, dengan meningkatnya kadar pati maka kadar glukosa yang diperoleh juga meningkat. 


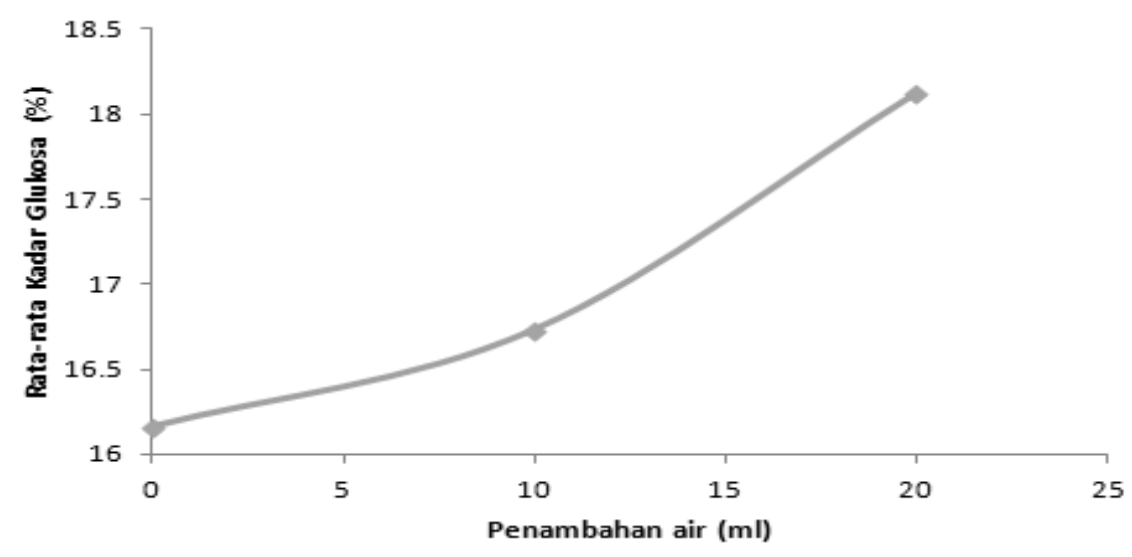

Gambar 3. Grafik Hubungan Penambahan air dengan Kadar Glukosa pada Paparan Radiasi Sinar Matahari

Dalam Gambar 3 terlihat bahwa dengan penambahan air maka kadar glukosa semakin meningkat, hal ini karena apabila pati ditambahkan air dingin maka granula pati akan menyerap air dan membengkak. Pembengkakan ini menyebabkan air terperangkap pada susunan molekul-molekul penyusun pati. Mekanisme pengembangan tersebut disebabkan karena molekul-molekul amilosa dan amilopektin secara fisik hanya dipertahankan oleh adanya ikatan hidrogen lemah. Atom hidrogen dari gugus hidroksil akan tertarik pada muatan negatif atom oksigen dari gugus hidroksil yang lain. Ketika sampel yang telah ditambahkan air tersebut dipapar radiasi matahari maka akan menyebabkan suhu sampel meningkat, sehingga ikatan hidrogen makin lemah, dan energi kinetik molekul-molekul air meningkat. Dengan demikian, akibat adanya peningkatan energi kinetik molekul air maka molekul-molekul air tersebut bergetar dan akibat getaran ini bisa melarutkan molekul-molekul amilosa dan amilopektin sehingga pati mengubahnya menjadi glukosa.

Tian et al., menyatakan bahwa bila pati dipanaskan dalam suhu kritikal dengan adanya air yang berlebih granula akan mengimbisi air, membengkak dan beberapa pati akan terlarut dalam larutan yang ditandai dengan perubahan suspensi pati yang semula keruh menjadi bening dan tentunya akan berpengaruh terhadap kenaikan viskositas dan kadar gula reduksinya [4].

\section{B. Paparan Gelombang Mikro}

Radiasi gelombang mikro yang kemudian terdisipasi menjadi panas, mampu menguraikan polisakarida menjadi monomer penyusunnya. Dari Gambar 3 terlihat bahwa pengaruh penambahan air pada paparan gelombang mikro terhadap kandungan glukosa 
sesuai dengan hipotesis. Semakin banyak penambahan air atau kandungan air maka semakin besar persentase kandungan glukosa diperoleh. Dengan demikian, jika penambahan air pada sampel dengan daya tetap dan lama pemaparan yang semakin meningkat maka dapat meningkatkan jumlah gula pereduksi.

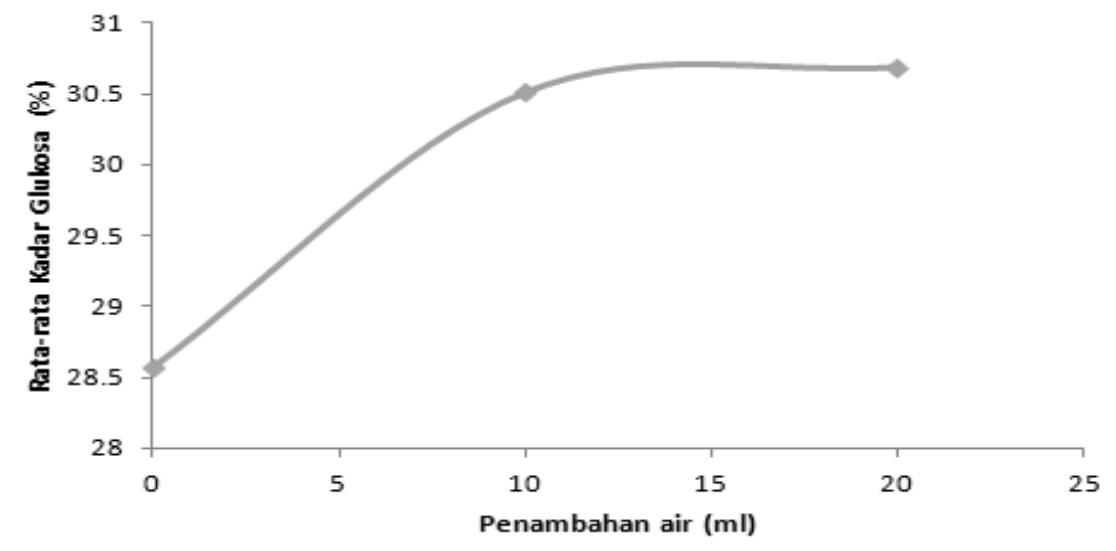

Gambar 4. Grafik Hubungan Penambahan Air dengan Kadar Glukosa pada Paparan Gelombang Mikro

Perbandingan peningkatan kadar glukosa pada bahan kering dan bahan dengan penambahan air sangat signifikan, hal ini karena semakin banyak air maka semakin banyak pula gelombang mikro yang terserap oleh air sehingga molekul-molekul yang terdapat dalam bahan akan semakin kuat bertumbukan karena gaya listrik yang diakibatkan medan listrik gelombang mikro akan memutar molekul-molekul yang bersifat polar atau mempunyai dua kutub positif dan negatif seperti air, dengan adanya tumbukan ini maka semakin lama akan menyebabkan adanya pemanasan sehingga dapat memecah ikatan molekul pada pati.

Mudgett (1886) menjelaskan bahwa kadar air merupakan faktor internal utama yang mempengaruhi kemampuan bahan-bahan dalam menyerap energi gelombang mikro, semakin banyak terdapat air, semakin tinggi loss factor dielectric dan menyebabkan pemanasan semakin baik hal ini disebabkan karena gelombang mikro akan ditarik oleh air [5]. Getaran pada molekul akibat radiasi gelombang mikro akan menghasilkan panas yang merata pada molekul tersebut, dimana gelombang elektromagnetiknya menembus molekul dan mengeksitasi molekul-molekul tersebut secara merata, tidak hanya permukaannya saja. Radiasi gelombang mikro mampu mempercepat reaksi dengan cara menggetarkan molekul reaktan dengan cepat. 


\section{Hidrolisis Asam}

Penambahan asam klorida pekat bertujuan untuk menghidrolisis pati karena pati dapat dihidrolisis sempurna dengan menggunakan asam sehingga menghasilkan glukosa. Setelah itu larutan dipanaskan, pemanasan bertujuan untuk mempercepat terjadinya hidrolisis, semakin lama pemanasan, maka semakin banyak pati yang akan terhidrolisis menjadi monosakaridanya yakni glukosa.

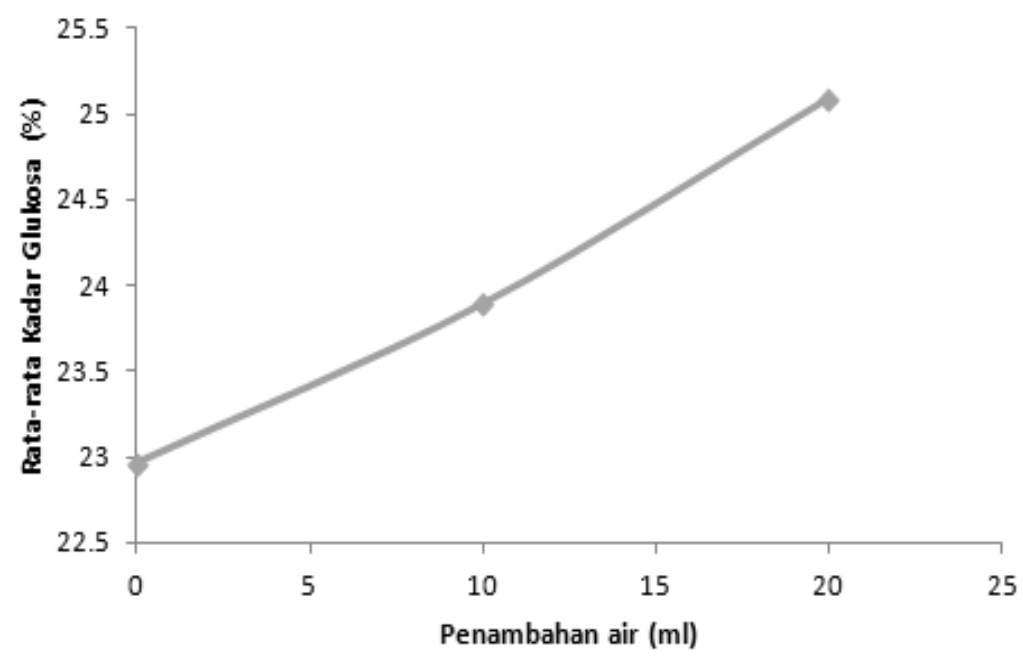

Gambar 5. Grafik Hubungan Penambahan Air dengan Kadar Glukosa pada Hidrolisis asam

Gambar 5 terlihat bahwa kadar glukosa yang dihasilkan antara sampel kering dan penambahan air memiliki perubahan kadar glukosa cukup besar, hal ini karena Pemanasan pati dengan air mengakibatkan putusnya ikatan hidrogen yang terdapat pada rantai polimer pati sehingga berefek melemahnya ikatan rantai polimer pati pada granula pati. Ketika ikatan polimer pada granula pati mulai melemah, granula akan menyerap air dan terjadi pengembungan pada granula pati dan pada saat itulah asam klorida bekerja sebagai katalis untuk memutus ikatan glikosidik $\alpha-1,4$ yang ada pada pati sehingga ukuran pati menjadi lebih kecil.

Hasil penelitian ini serupa dengan penelitian sebelumnya yang menyatakan jumlah air yang digunakan sebagai reaktan akan menentukan derajat hidrolisis dan kondensasi sehingga akan berpengaruh pada kadar glukosa [6]. Variasi volume air serta menggunakan katalis asam klorida. memiliki beberapa kelebihan, yaitu harganya lebih murah, lebih cepat dalam menghidrolisis, mudah didapat dan rendemen gula lebih tinggi jika dibandingkan dengan hidrolisis enzim. 


\section{Perbandingan Kadar Glukosa}

Hidrolisis dengan menggunakan gelombang mikro memiliki berbagai kelebihan dibandingkan dengan metode hidrolisis yang lain, diantaranya waktu hidrolisis lebih singkat, pemanasan lebih merata, dan kebutuhan pelarut lebih sedikit. Akan tetapi pada paparan ini membutuhkan daya dan energi yang lumayan besar.

Pada penelitian ini, perubahan kadar glukosa dengan paparan gelombang mikro dibandingkan dengan paparan radiasi matahari dan hidrolisis asam. Waktu yang dibutuhkan pada paparan gelombang adalah selama 30 menit, sedangkan paparan radiasi matahari adalah 1 jam dan dengan hidrolisis asam membutuhkan waktu selama 80 menit (kondisi bahan baku (bonggol pisang) disamakan, yaitu dikeringkan terlebih dahulu selama 5 hari). Dari segi ekonomis, masyarakat bisa menggunakan paparan radiasi matahari untuk meningkatkan kadar glukosa yang akan digunakan untuk membuat bioetanol, namun dari segi efisiensi maka yang terbaik adalah dengan menggunakan gelombang mikro.

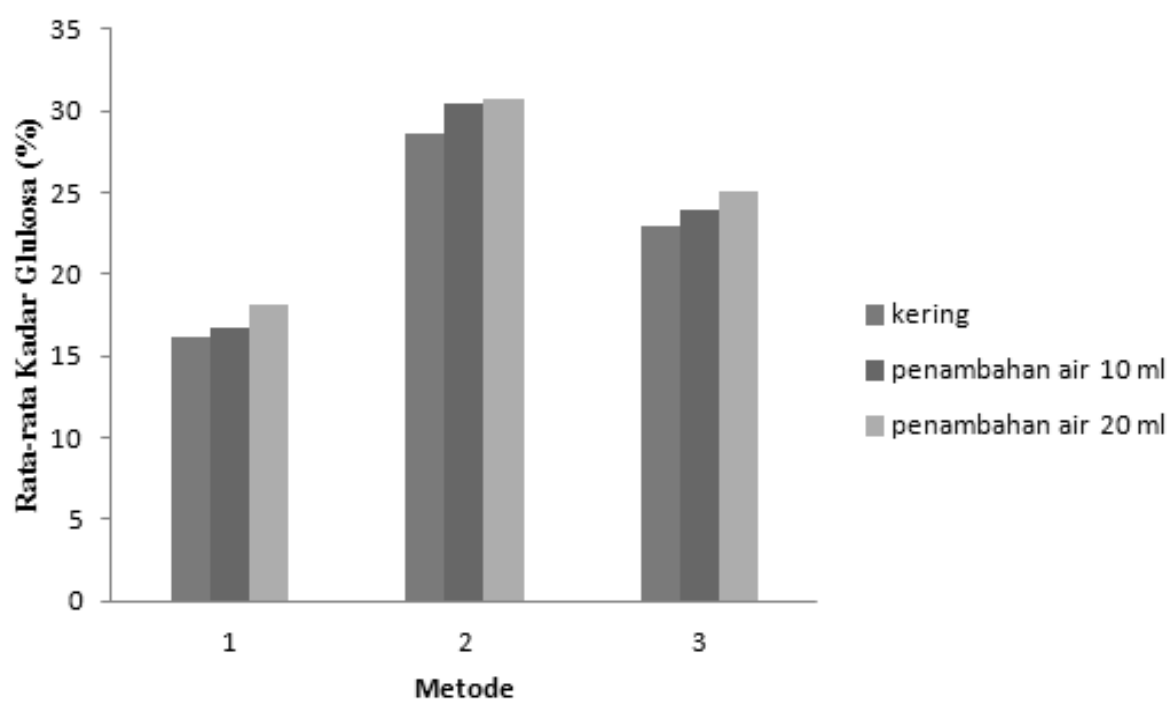

Gambar 6. Grafik Perbandingan Metode dengan Kadar Glukosa

Gambar 6 menunjukkan bahwa perolehan kadar gula paling banyak adalah dengan menggunakan gelombang mikro. Tingginya perolehan kadar glukosa pada hidrolisis dengan menggunakan gelombang mikro disebabkan oleh aktivitas molekul-molekul air yang memicu terjadinya pembengkakan material tanaman akibat adanya pemanasan dielektrik. 


\section{KESIMPULAN}

Berdasarkan data dan grafik yang diperoleh dari penelitian dapat disimpulkan bahwa:

1. Penambahan kadar air pada serbuk bonggol akan mempengaruhi peningkatan kadar glukosa pada saat proses hidrolisis dari tiap-tiap metode. Pada pemaparan matahari diperoleh nilai kadar glukosa tertinggi dengan penambahan air $20 \mathrm{ml}$, yaitu $18.15 \%$. Sedangkan pada paparan gelombang mikro diperoleh $30.89 \%$ dengan penambahan kadar air $20 \mathrm{ml}$, dan untuk metode hidrolisis asam kadar glukosa tertinggi diperoleh sebanyak $29.15 \%$ dengan penambahan kadar air $20 \mathrm{ml}$.

2. Peningkatan kadar glukosa juga dipengaruhi oleh metode yang digunakan untuk proses hidrolisis. Dari grafik perbandingan diperoleh metode terbaik untuk menghidrolisis pati menjadi glukosa adalah dengan pemaparan gelombang mikro serta penambahan air $20 \mathrm{ml}$.

\section{DAFTAR PUSTAKA}

[1] Husnil, Y. A. 2009. Perlakuan Gelombang Mikro dan Hidrolisis Enzimatis pada Bambu untuk Produksi Bioetanol. Tesis Program Magister. Departemen Teknik Kimia Fakultas Teknik Universitas Indonesia. Depok

[2] Kartikasari, Ratna. 2012. Pengaruh Paparan Gelombang Mikro Terhadap Biomassa Jerami Padi. Tugas Akhir. Tidak diterbitkan. Malang: Jurusan Fisika Fakultas Sains dan Teknologi Universitas Islam Negeri Maulana Malik Ibrahim

[3] Prihandana. 2007. Bioetanol Ubi kayu Bahan Bakar Masa Depan. Agromedia. Jakarta

[4] Tian, George. 1991. The Enzymatic Production of Glucose Syrups. Dalam S.Z.Dziedzic dan M.W Kearsly (eds). Glucose Syrups: Science and Technology. London and New York: Elsevier Applied Science Publisher

[5] Prastyanty, R. 1996. Isotermi Sorpsi Air dan Kerenyahan Krupuk Goring Dengan Penggorengan Oven Gelombang Mikro. Skripsi Jurusan Teknologi Pangan dan Gizi. Fakultas Teknologi Pertanian Bogor

[6] Khairani, Rini. 2007. Tanaman Jagung Sebagai Bahan Bio-fuel. http://www.macklintmip-unpad.net/Bio-fuel/Jagung/Pati.pdf. diakses tanggal 25 Maret 2009 